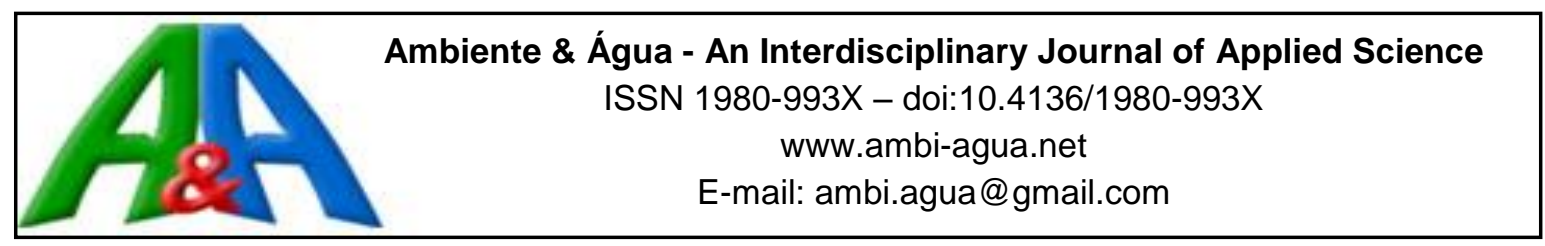

\title{
Shifting habitat mosaic: identification and mapping
}

\author{
ARTICLES doi:10.4136/ambi-agua.2242
}

Received: 13 Mar. 2018; Accepted: 18 Dec. 2018

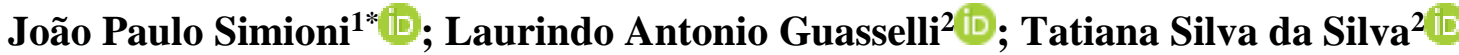 \\ ${ }^{1}$ Universidade Federal do Rio Grande do Sul (UFRGS), Porto Alegre, RS, Brasil \\ Centro Estadual de Pesquisas em Sensoriamento Remoto e Meteorologia (CEPSRM). \\ E-mail: joao.delapasse@ufrgs.br \\ ${ }^{2}$ Universidade Federal do Rio Grande do Sul (UFRGS), Porto Alegre, RS, Brasil \\ Instituto de Geociências (IGeo/UFRGS). \\ Centro Estadual de Pesquisas em Sensoriamento Remoto e Meteorologia (CEPSRM). \\ E-mail: laurindo.guasselli@ufrgs.br, tatiana.silva@ufrgs.br \\ *Corresponding author
}

\begin{abstract}
The Shifting Habitat Mosaic refers to temporal changes in the spatial pattern of habitats, through the flood and dry pulses. This work mapped the dynamics of a Shifting Mosaic associated with the flood and dry pulses in the Environmental Protection Area of the Banhado Grande (EPABG). The research was divided into four stages: i) acquisition of satellite images; ii) obtaining rainfall river basin data from the Gravataí River; iii) identification of the flood and dry pulses; and iv) mapping of the Shifting Mosaic in the wetlands of the EPABG. In large swaths of flooding, a shifting connectivity is established between the AUs of EPABG, providing several interactions among these wetlands, such as nutrient exchange, sediments and living organisms. It was found that in periods where the accumulation of precipitation in the last 30 days is greater than $200 \mathrm{~mm}$, we have the presence of predominantly aquatic mosaic with the presence of predominantly aquatic animals and vegetation; In periods where the cumulative precipitation in the 30 days is less than $200 \mathrm{~mm}$, a terrestrial mosaic predominates, with increase of ciliary vegetation.
\end{abstract}

Keywords: floodplain, flood pulses, shifting mosaic, wetlands.

\section{Mosaico de habitat móvel: identificação e mapeamento}

\section{RESUMO}

O Mosaico de Habitat Móvel (SHM) refere-se às mudanças temporais no padrão espacial dos habitats, através dos pulsos de inundação e seca. Este trabalho teve por objetivo mapear a dinâmica de um Mosaico Móvel associado aos pulsos de inundação e seca, na Área de Proteção Ambiental do Banhado Grande (APABG). A realização desta pesquisa dividiu-se em quatro etapas: i) aquisição das imagens de satélite; ii) obtenção dos dados de precipitação pluviométrica e de cota do rio Gravataí; iii) identificação dos pulsos de inundação e seca; e iv) mapeamento do Mosaico Móvel nas Áreas Úmidas da APABG. Em grandes pulsos de inundação se estabelece, no mosaico móvel, uma conectividade entre as AUs da APABG, proporcionando diversas interações entre essas AUs, tais como, troca de nutrientes, sedimentos e organismos vivos. Identificou-se que em períodos onde o acumulado de precipitação nos 
últimos 30 dias é maior que $200 \mathrm{~mm}$, tem-se a presença de um mosaico predominantemente aquático com a presença de peixes e macrófitas; já em períodos onde o acumulado de precipitação nos 30 dias é menor que $200 \mathrm{~mm}$, predomina-se um mosaico terrestre, com aumento da vegetação ciliar.

Palavras-chave: áreas úmidas, mosaico móvel, planície de inundação, pulsos de inundação.

\section{INTRODUCTION}

Considered environments of high productivity and ecological value, flood plains are areas flooded by the lateral overflow of rivers or lakes, by the rainwater or groundwater (Schindler et al., 2014). Due to phytosociological features and substrates, they constitute a variety of ecosystems (Haines-Young et al., 2012).

The flood plains can be called the Aquatic/Terrestrial Transition Zone - ATTZ. This alternation between aquatic and terrestrial increases the decomposition of organic matter and the nutrient cycling, in addition to reducing the periods of stagnation in comparison with the conditions in permanently flooded habitats (Tracy-Smith et al., 2012).

Neiff (2003) points out that the transition concepts, ecotone and wetlands have been used without considering their conceptual differences. For floodplains to be ecotones (intermediate areas of tension between two communities) the physicochemical environment should have a flotation system (climate, hydro-sedimentological) that is difficult to predict. Also, populations of narrow niches should predominate (estenotípicos) as ecotone components.

However, the floodplain areas are constant in time and their operation is predictable (Schindler et al., 2014) due to the regularity of flood pulses (Junk, 2015). Therefore, environments commonly with flood pulses have no ecotone features, being characterized as macro-ecosystems that have no transitional features between terrestrial and aquatic ecosystems (Neiff, 2003).

Nevertheless, there may exist locally and continuous ecotones in some flood plains, depending on the degree of environmental interactions and the hydrological regime associated with flood pulses (Piazza, et al., 2014). As a result this highly complex structure of floodplains, there is the formation of functional landscape mosaics as from the drastic seasonal changes to which the system is periodically subject (Milne and Bennett, 2007).

Stanford et al. (2005) deal with these mosaics as "Shifting Habitat Mosaic" (SHM) that change seasonally, determining an important spatiotemporal variability, characterized by the presence of habitats that interrelate in different degrees (Lim et al., 2016).

The SHM refer to temporal changes in landscape fragments, which are presented sometimes dry, sometimes flooded, with exposed vegetation or soil. These changes seasonally create a mosaic of landscapes by natural processes such as floods, mass movements, fluvial deposits, defrosting, etc., but also by human activities such as burnings, deforestation and dams (Engle et al., 2008).

In floodplains, the SHM approach recognizes that the interactions between physical and biotic processes produce constant changes of its spatial pattern through flood pulses (Wang and Finley, 2011).

The concept of flood pulse (Junk, 2005) considers the lateral exchanges between the river and its floodplain, as well as the change and exchanges between the terrestrial (dry) and aquatic (flood) phases on the same plain. Therefore, the system can incorporate and efficiently take advantage of the organic matter, which explains the richness and diversity of rivers with floodplains (Sanches et al., 2012).

Studies involving SHM are characterized by a multidisciplinary approach: Wimberly (2006) deals with the dynamics of species in degraded landscapes, to understand if the 
connectivity (Tischendorf and Fahrig, 2000; Luque et al. 2012) between landscapes is influenced by SHM; Engle et al. (2008) analyze the sensitivity of the invertebrate community; Armstrong and Schindler (2013) analyzed the relationship between the water temperature and the spatial distribution of the silver-Salmon (Oncorhynchus kisutch), address the restoration of successional dynamics of a SHM in a floodplain.

Thus, this study maps the dynamics of a SHM associated with flood pulse and drought in the connectivity area between the Wetlands of Environmental Protection Area of Banhado Grande (EPABG).

\section{MATERIAL AND METHODS}

\subsection{Study area}

The Environmental Protection Area of Banhado Grande was established by State Decree N. 38,971/1998, and its basic objectives are to protect biological diversity, to discipline the occupation process and to ensure the sustainable use of natural resources (Brenner, 2016).

Located in the Metropolitan Region of Porto Alegre (MRPA), the EPABG has an area of 136,935 ha, covering the municipalities of Santo Antonio da Patrulha, Gravataí, Viamão and Glorinha (Figure 1) (Brenner, 2016; Simioni et al., 2017).

The EPABG comprises three areas of marsh, the Banhado Grande, the Banhado Chico Lomã and the Banhado dos Pachecos, which form a large composition of wetlands in the basin of the Gravataí River, defined as Banhado Grande System (BGS) (Scherer, 2014). The BGS is delimited by an altimetry quota of $20 \mathrm{~m}$, and according to Accordi and Hartz (2006) it consists of a continuous area of swamps or marshes, flooded lands and rice fields.

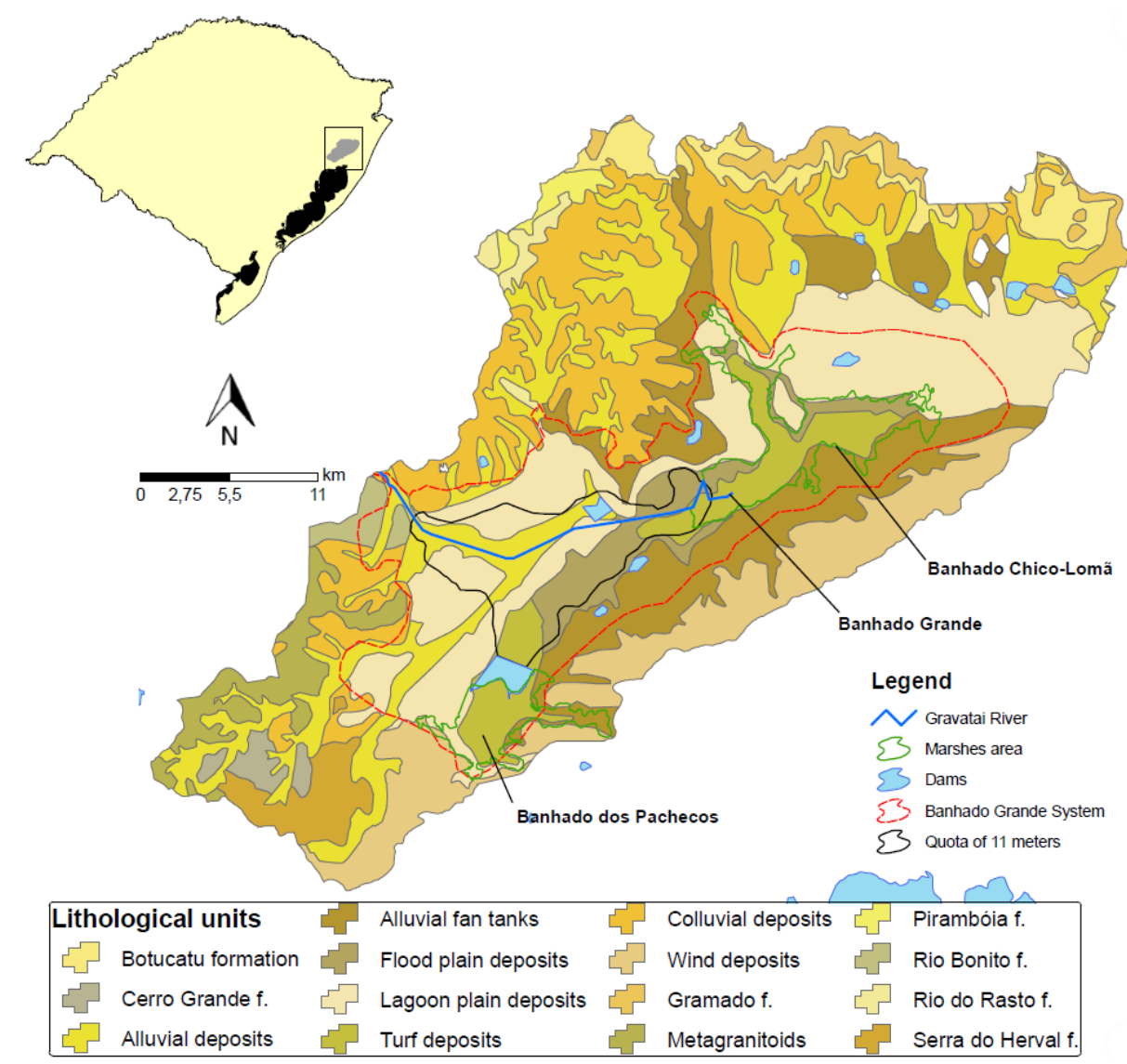

Figure 1. Lithology of the Environmental Protection Area of Banhado Grande, RS. 
According to the geological map (Figure 1), the BGS area consists of four geological compartments: lagoon plains deposits, peat deposits, alluvial deposits and floodplain deposits. The areas of marshes associated with turf deposits are found in areas where the marshes of Banhado Grande, Chico-Lomã and Pachecos are located (Scherer, 2014). In large flood pulses, a polygon associated with $11 \mathrm{~m}$ quota floods connects (Simioni et al., 2017) the areas of Banhado Grande and Pachecos and the floodplain of the Gravataí River.

EPABG is part of the Subtropical Climate III (Rossato, 2011), with its average annual temperature ranging between 17 and $20^{\circ} \mathrm{C}$ and pluviometric regime between 1,700-1,800 mm per year (Alvares et al., 2013). The monthly average rainfall between 1981-2010 in the INMET Meteorological Station in Porto Alegre is $112.6 \mathrm{~mm}$. The months with the lowest average rainfall (dry) are April, May and December, with $86 \mathrm{~mm}, 95 \mathrm{~mm}$ and $100 \mathrm{~mm}$, respectively (Inmet, 2016). On the other hand, the months with the highest average rainfall (floods) are June, August and September, with $135 \mathrm{~mm}, 140 \mathrm{~mm}$ and $139 \mathrm{~mm}$, respectively.

\subsection{Methodological procedures}

The work was divided into four stages: i) the acquisition of satellite images; ii) obtaining the rainfall and the Gravataí River quota data compatible with the dates of the images; iii) identification of the flood pulse and drought in the polygon area concerning the quota of 11 meters; and iv) mapping of the SHM in the wetlands of APABG.

Unlike Stanford et al. (2005) which defined the term SHM, this work will only address the spatialization of a SHM, associated with a flood pulse (Junk, 2005) and drought, in the polygon area associated with elevation of $11 \mathrm{~m}$.

\subsection{Acquisition of Satellite Images}

The satellite images were obtained from the USGS website (United States Geological Survey). We chose to work with images in periods of large flood pulses and drought. Six Landsat images were selected from 1983 to 2014, Table 1.

Table 1. Landsat TM images utilized.

\begin{tabular}{lccc}
\hline Image Date & Satellite & Cumulative rainfall in 30 days (mm) & Quota (m) \\
\hline $11 / 24 / 1983$ & Landsat 4 & 186.5 & 2.3 \\
$09 / 21 / 1992$ & Landsat 4 & 111.1 & 2.8 \\
$10 / 21 / 2000$ & Landsat 7 & 250.8 & 4.5 \\
$04 / 29 / 2009$ & Landsat 5 & 31.0 & 0.9 \\
$08 / 31 / 2013$ & Landsat 8 & 247.5 & 5.5 \\
$10 / 21 / 2014$ & Landsat 8 & 204.3 & 4.6 \\
\hline
\end{tabular}

\subsection{Rainfall and River level quota}

The rainfall data were obtained from the website of the Brazilian Institute of MeteorologyINMET, daily rainfall data for the 30 days prior to obtaining the satellite images.

On the Weather Forecasting and Climate Studies Center - CPTEC/INPE website, event data were obtained from El Niño and La Niña, to relate to the flood pulses and drought in the wetlands of EPABG.

For the data analysis of variations in the level of the river quota, the measurement gauge of Passo das Canoas was used as the basis, administered by the Mineral Resources Research Company (CPRM), installed in Gravataí, available in the system of the Hidroweb of the National Water Agency (ANA). 


\subsection{Identification of pulses flood and drought}

To identify and map the flood pulses and drought (Junk et al., 2012) in EPABG, the Normalized Difference Water Index - NDWI was used (Gao, 1996), using satellite images from Landsat 4, 5 TM and 7 ETM+, Equation 1:

$N D W I=\frac{(B 2-B 4)}{(B 2+B 4)}$

Where: B2 - green wavelength; and B4 - near infrared.

And to calculate the NDWI using Landsat 8 OLI images, Equation 2:

$N D W I=\frac{(B 3-B 5)}{(B 5+B 5)}$

Where: B3 - green wavelength; and B5 - near infrared.

The NDWI images (Gao, 1996) have identified the flood pulses and drought. The six images used were added through the Raster Calculator tool. The NDWI images were overlapped on the polygon referring to the limits of EPABG quantified floodplains located in the EPA. The calculation was performed using the ArcGIS Calculate Geometry tool.

\subsection{Characterization of the Shifting Habitat Mosaic}

The methodology of Kleindl et al. (2015) was adapted to characterize the SHM in the wetlands of the EPABG. The focus of this work is the river-floodplain system and wetlands dynamics in the corridor between two major wetland areas, Banhado Grande and Pachecos, considering an 11-meter quota. Differently from Kleindll et al. (2015), this study analyzed these areas using only data derived from remote sensing, measured precipitation data, and quota level data of Gravataí River, to understand and characterize the dynamics of an SHM in the EPABG.

The study of Kleindll et al. (2015) consisted in analyzing the expansion of a floodplain due the forest fires, using the concept of SHM. The authors worked with remote sensing images, rainfall data, outflow data (empirical and shaped), and data on the extension and frequency of forest fires of the past, to examine the relations between hydrology, fire, land use, as well as geomorphological and dynamic position of the SHM. In this way, the authors had concluded that the current composition of the SHM in the area of the floodplain of the River Flathead resulted from diverse interactions between flooding events, erosive processes, and forest fires, influenced by the geomorphic composition of the floodplain.

\section{RESULTS}

The average annual growth (1973-2014) of the river-level maximum quota, as registered by the measurement gauge of Passo das Canoas, in the Gravataí River (Figure 2), shows a range between $1.25 \mathrm{~m}$ to $2.70 \mathrm{~m}$ over the 41 years of analysis.

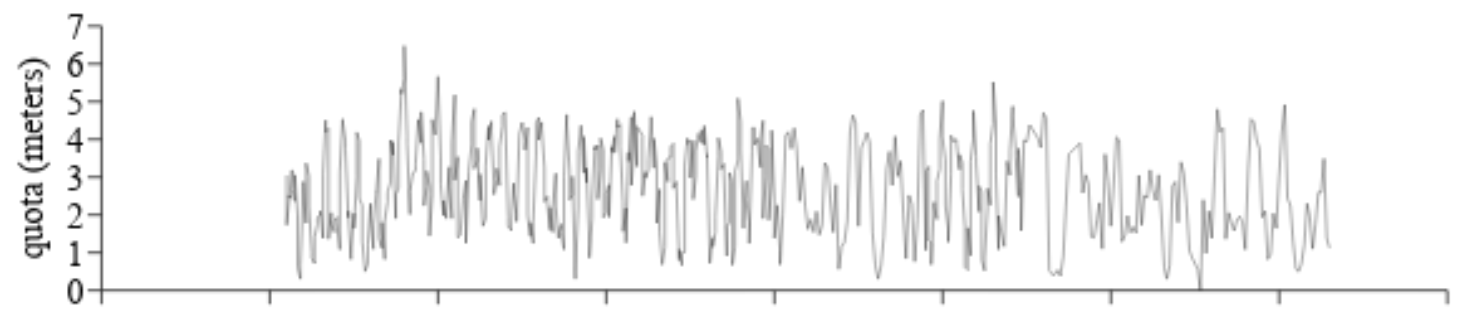

Figure 2. Monthly variation (1980-2014) of the maximum quota as measured by the measurement gauge of Passo das Canoas, Gravataí River. 
According to Brazil (Inmet, 2016), the years of occurrence of the El Niño classified as "strong" were 1983, 1986-1988, 1991-1992, 1997-1998, 2002 and 2009-2010. In these years, water levels were higher when compared to other years analysed. In all the years of occurrence of El Niño considered strong by the CPTEC/INPE, the average fluctuation of water levels was higher than $2.00 \mathrm{~m}$.

On the other hand, the La Niña events, considered strong by the CPTEC/INPE, occurred in the years of 1988-1990 and 2006-2008. These years were those which had the lowest maximum monthly values of water level elevation in the Gravataí River (1.25 to $1.50 \mathrm{~m})$ (Inmet, 2016).

Figure 3 shows the rainfall and the Gravataí River quota for the 30 days preceding the date of satellite images. The years 1983 (Figure 3a) and 2009 (Figure 3d) were characterized by the strong influence of the La Niña (Inmet, 2016). Rainfall totals in the official INMET Meteorological Station in Porto Alegre were $186.5 \mathrm{~mm}$ and $31.0 \mathrm{~mm}$, respectively, and the quotas were $2.3 \mathrm{~m}$ and $0.9 \mathrm{~m}$. In Figs. 3b, 3c, 3e and 3f, the events of the El Niño are highlighted. In Figure 3b, it rained $101.1 \mathrm{~mm}$, and the Gravataí River quota reached its maximum value for the period $(4.25 \mathrm{~m})$.
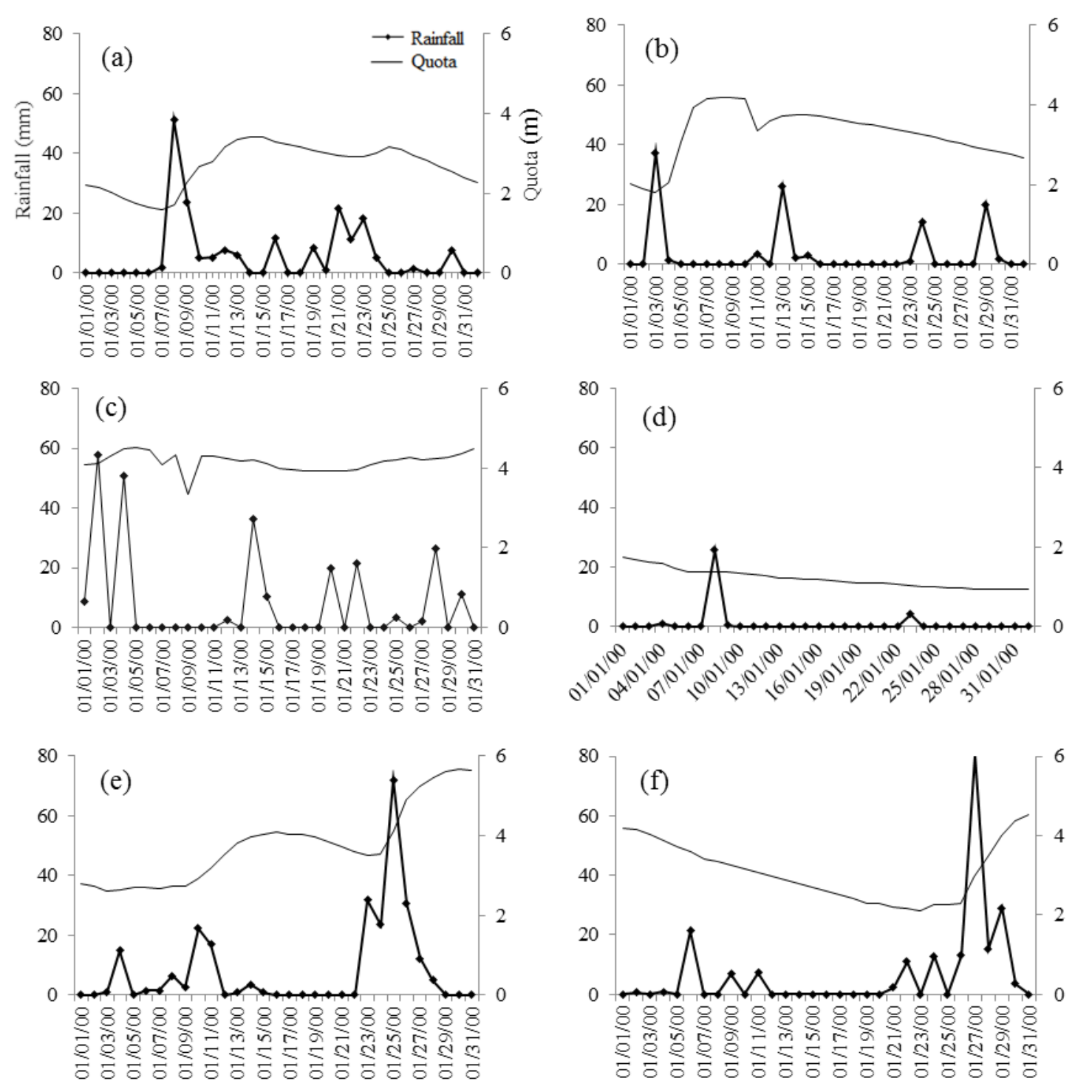

Figure 3. Relationship between the accumulated rain and the Gravataí River quota. 
Figure $3 \mathrm{c}$ shows the highest rainfall, detected of $250.8 \mathrm{~mm}$, distributed in 14 days. However, since the maximum rainfall peak occurred 20 days before obtaining the image, this period did not present the highest Gravataí River quota, which marked $4.5 \mathrm{~m}$.

According to Colombo and Pessoa (2013), the year of 2009 was characterized by a severe drought in Rio Grande do Sul, causing several impacts, especially on the economy of the state. The year of 2009, Figure 3d, was the one with the lowest rainfall, when it rained a total of $31.0 \mathrm{~mm}$. As a result, this period also had the lowest quota in the level of the Gravataí River $(0.9 \mathrm{~m})$.

In Figure 3e, the rainfall value recorded between August 25th and 26th, 2013 is highlighted, $72 \mathrm{~mm}$. This amount resulted in the highest Gravataí River quota among the analyzed dates $(5.5 \mathrm{~m})$.

Similar to the date of 2013, Figure $3 \mathrm{f}$ also presents only one maximum rainfall peak, verified on 17 October 2014, when it rained $80 \mathrm{~mm}$ in 24 hours. This peak increased the Gravataí River quota in more than $2 \mathrm{~m}$. The quota value was $2.5 \mathrm{~m}$, and at the time of image acquisition the registered quota was $4.6 \mathrm{~m}$.

Figure 4 refers to the flooded area for each Landsat image. The accumulated precipitation was $186.5 \mathrm{~mm}$, and flooded area in the polygon referring to the quota of 11 meters was 367.4 ha, corresponding to $3.8 \%$ polygonal area (Figure 4a). This area is located mostly in the floodplain of the Gravataí River, in the area popularly known as Anastacia Lagoon. On that date, the two dams did not exist, located within and south of the polygon related to the 11-meter quota. The Gravataí River quota level on the date of the image was $2.3 \mathrm{~m}$.

In Figure 4b, the two dams already existed. The accumulated rainfall was $111.1 \mathrm{~mm}$ and the flooded area was 322.5 ha. The quota of the Gravataí River on the date of the image was $2.8 \mathrm{~m}$. Figure $4 \mathrm{c}$ presents, along with Figure 4e, larger amounts of accumulated precipitation, $250.8 \mathrm{~mm}$ and $247.5 \mathrm{~mm}$, respectively. Consequently, these figures show the biggest flooded areas among the analyzed images, $7577.5 \mathrm{ha}$, and in Figure $4 \mathrm{c}$ and 7853.9 ha in Figure 4e. The quota of the Gravataí River on the dates of the images was $4.5 \mathrm{~m}$ and $5.5 \mathrm{~m}$, respectively.

Figure $4 \mathrm{~d}$ shows a period of drought, the flooded area was 67.5 ha. The quota of the Gravataí River in Figure 4d was 0.9 m. In Figure 4f, the flooded area is 3,796 ha and the accumulated rainfall $204.4 \mathrm{~mm}$. The quota of the Gravataí River on this date was 4.6 meters.

It is understood, therefore, that when the accumulated precipitations are greater than 200 $\mathrm{mm}$, during 30 days, SHM are formed in the EPABG wetlands. Figure 5 shows a SHM in the EPABG wetlands. The rectified stretch of the Gravataí River is highlighted, near the area known as Anastacia Lagoon. In this area, the river flood pulses create a mosaic that seasonally alternates between aquatic and land, being responsible for the habitat heterogeneity (Junk et al., 1989). In Figure 5a, the drought period, there is a predominance of a terrestrial environment. The flooded area is restricted to the main channel (rectified) and the intricacies that, although abandoned, still remain active in Anastasia Lagoon. This lagoon is erroneously named as such, since this environment is just an old meander of the Gravataí River, which was closed by rice farmers to stop the water so that it could be used for crop irrigation.

Figure 5b shows a flood period in the Gravataí River. It is noticeable that the meanders are completely flooded, forming a predominantly aquatic SHM that remains until the recession of the waters, which lasts from 15 to 30 days. 


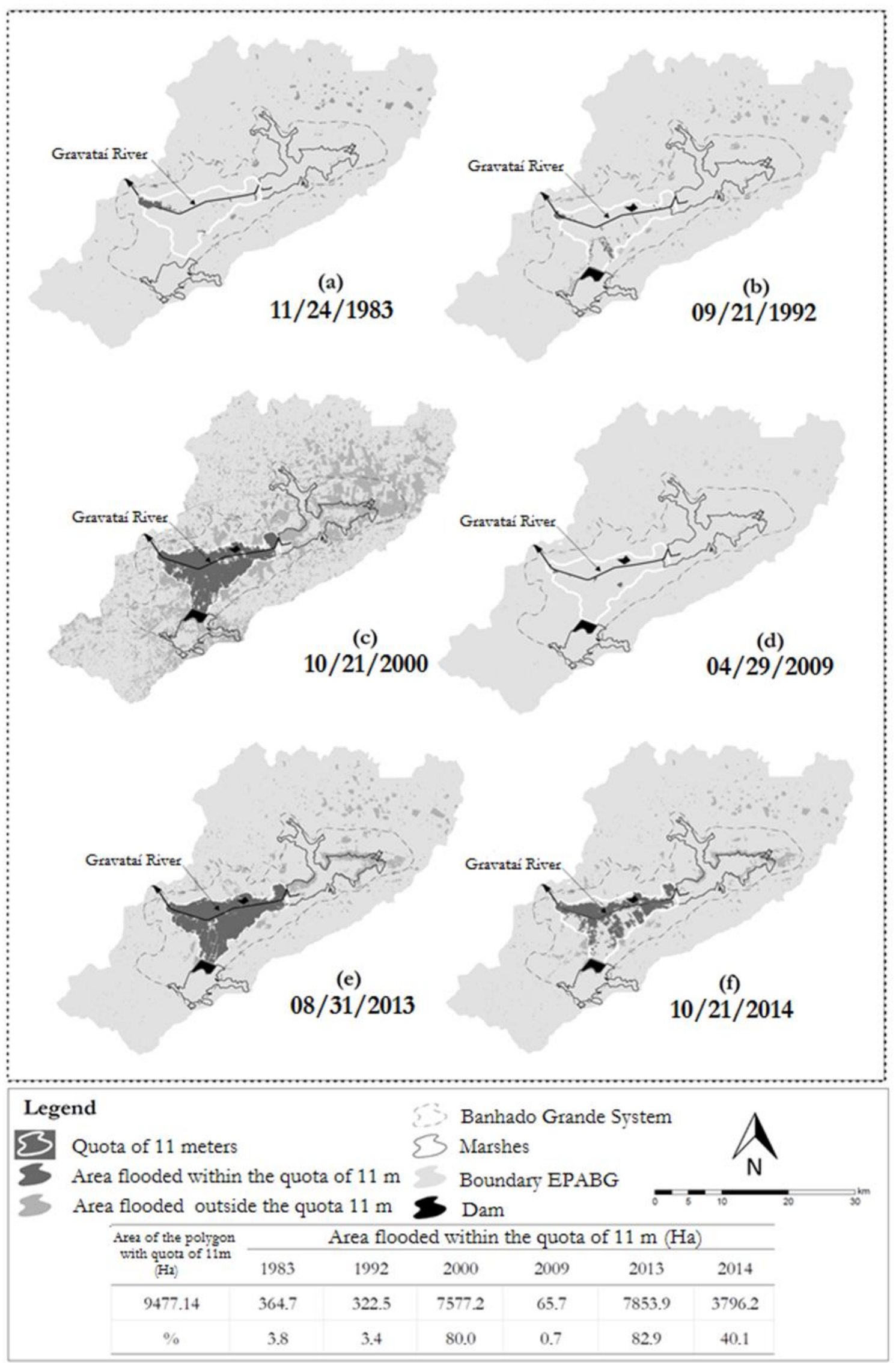

Figure 4. Flood area for the studied images. 


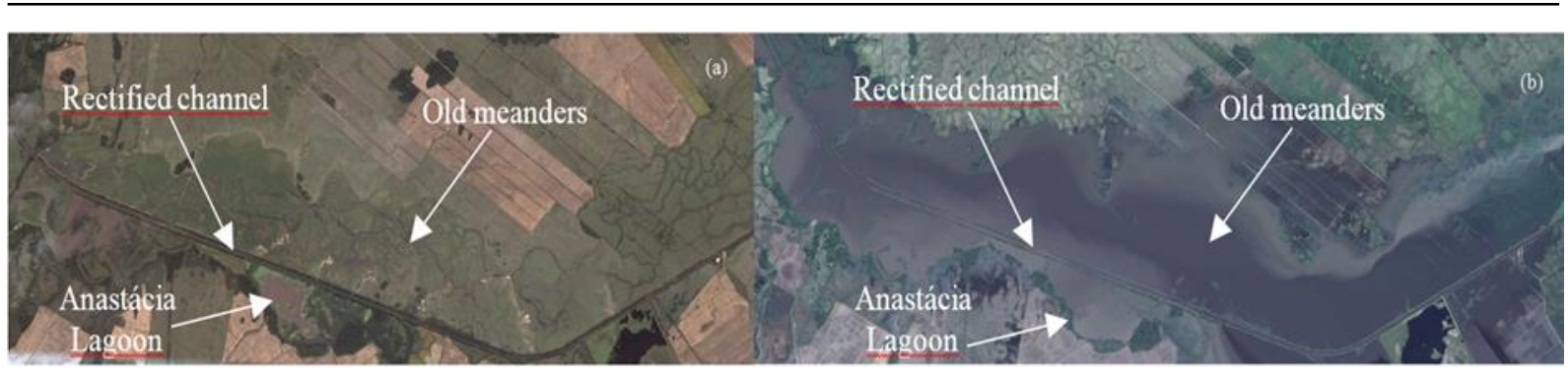

Figure 5. Shifting Mosaic in a rectified section of the Gravataí River: (a) dry phase, 04/30/2009; and (b) flooded phase, 08/11/2011.

Source: Google Earth Pro (2016).

\section{DISCUSSION}

The quota of the Gravataí River is considered normal between 2.70 to $3.00 \mathrm{~m}$, on the measurement gauge of Passo das Canoas (Relf, 2015). From the quota of $4.5 \mathrm{~m}$, the Gravataí River begins to overflow, and riverine families need to be relocated (Relf, 2015). Still, in the 1970s, part of the Gravataí River was rerouted with the intention of draining the wetlands, seeking to expand the areas intended for rice cultivation (Brenner, 2016).

However, despite the correction, the area near the Anastacia Lagoon remains with its old meanders, being horizontally connected to the river, in large flood pulses. In this area, Brenner (2016) has proposed measures to return the meanders to a more-natural state, using bioengineering techniques. This process would reduce the speed of the water runoff, since the channel would go from rectilinear to meandering, reducing erosion problems and drainage of wetlands.

Regarding the discharge, according to the Institute of Hydraulic Research (IPH, 2002), the minimum discharge of 7 days to 10 years of TR (Q 7.10) in the post of Passo das Canoas (located at the boundary between the low and medium Gravatai) is $6.02 \mathrm{~m}^{3} / \mathrm{s}$, which corresponds to $25 \%$ of the long-period average. For the same post, the discharge full of TR of 10 years and 100 years are respectively $206 \mathrm{~m}^{3} / \mathrm{s}$ and $311 \mathrm{~m}^{3} / \mathrm{s}$.

Simioni et al. (2017) point out that the DNOS report in 1985, analysing of the number of flow rates from 1940 to 1981, states that the course correction of the channel did not cause changes in the water regime, nor an increase in flow of the Gravataí River.

However, according to the authors, through the analysis of the flow in the period after 1981 , the increase of flow in the post-correction period is evident. The maximum flow rates (Rio Grande do Sul, 2011) increased due to the ease of flow provided by the correction. The river course, when meandering, favored the decrease in the flow speed and, with the correction, the rectilinear course favored the increased flow speed (Brenner, 2016). In Figure 5, the images allow easy identification of the SHM providing a concise overview of rivers, even for nonscientists (Stanford et al., 2005).

Thus, when analyzing the maps of variation of the SHM, it is possible to realize that the fluvial action of floods and temporal migration of the channel, especially in Anastacia Lagoon, create different SHM through the riverside landscape (Stanford et al. 2005).

Thus, ecotones (present in the floodplain) (Neiff, 2003), connectivity (between Banhados Grande, Pachecos and the floodplain of the Gravataí River) (Vanderhoof et al., 2016; Simioni et al., 2017) and succession play important roles in the structuring of spatiotemporal heterogeneity that leads to high biodiversity that characterizes the Gravataí River (Rio Grande do Sul, 2011; Cardoso, 2016).

In periods of great flood pulses, this connectivity established between the wetlands of EPABG, especially in the corridor that connects the Banhado Grande, Pachecos and floodplain of the Gravataí River, provides several interactions between wetlands, such as the exchange of nutrients, sediments and organisms (Vanderhoof et al. 2016). 
Given this ecological dynamism, Wang and Finley (2011) pointed out how critical this is to managers of Conservation Units (CU's), because they often choose to preserve the shape of the landscape in its present condition, or lead to landscape back to some historical appearance based on studies of changes in the landscape. The interference in natural patterns alters or disturbs the ecological flows. So, if the goal is to maintain the natural ecosystem processes, it should be accepted that the configuration of the landscape is changing over time (Wang and Finley, 2011).

Temporal shifts in the mosaic associated with temporal changes in the main channel and in the floodplains create fragments with different environmental conditions (Lima et al., 2013), the SHM. These conditions are directly related to the dynamics of the EPABG wetlands, which are presented sometimes dry, sometimes flooded, forming the SHM, with the growth of the vegetation and the presence of land animals in dry periods, and the presence of fish and aquatic plants in flood periods (Cardoso, 2016).

Furthermore, Tittensor (2013) states that the result of SHM in flood plains are considered productivity hotspots because they provide the proliferation of algae during the flood and enrichment of nutrients in the soil after drought.

Additionally, according to Junk et al. (2012), the wetlands along small rivers, small depressions, such as wetlands of the EPABG, have an unpredictability in the occurrence of flood pulses (Neiff, 2003), and its amplitude is variable. Given this, the characterization of the SHM in the wetlands of EPABG is essential, as it allows us to understand the dynamics and compartments subject to the formation of this mosaic.

\section{CONCLUSION}

The satellite images allowed concise mapping of the SHM in EPABG. It was found that in periods where the cumulative rainfall in the past 30 days is greater than $200 \mathrm{~mm}$, there is the presence of a predominantly aquatic mosaic on the polygon referring to the $11 \mathrm{~m}$ quota, with the presence of amphibians, reptiles, fish and birds that depend on them for feeding.

On the other hand, in periods where the cumulative rainfall is less than $200 \mathrm{~mm}$, a terrestrial mosaic predominates, with the increase of riparian vegetation and animals, especially amphibians and mammals. Regarding the methodology, it's adaptation allowed the analysis and spatial distribution of the SHM throughout the polygon area concerning the $11 \mathrm{~m}$ quota, not restricting it only to the temporal displacement of the meanders.

\section{REFERENCES}

ACCORDI, I. A.; HARTZ, S. M. Distribuição espacial e sazonal da avifauna em uma área úmida costeira do sul do Brasil. Revista Brasileira de Ornitologia, v. 2, p. 117-135, 2006.

ALVARES, C. A.; STAPE, J. L.; SENTELHAS, P. C.; GONÇALVES, J. L. M.; SPAROVEK, G. Köppen's climate classification map for Brazil. Meteorologische Zeitschrift, v. 22, n. 6, p. 711-728, 2013. https://doi.org/10.1127/0941-2948/2013/0507

ARMSTRONG, J.; SCHINDLER, D. Going with the Flow: Spatial Distributions of Juvenile Coho Salmon Track an Annually Shifting Mosaic of Water Temperature. Ecosystems, v. 16, n. 8, p. 1429-1441, 2013. https://doi.org/10.1007/s10021-013-9693-9

BRENNER, V. Proposta metodológica para renaturalização de trecho retificado do rio Gravataí-RS. 2016. Dissertação (Mestrado em Geografia) - Instituto de Geociências, UFRGS, Porto Alegre, 2016. 
CARDOSO, S. Flora e Fauna do rio Gravataí e ecossistemas associados. Gravataí: Projeto rio limpo, 2016.

COLOMBO, J. A.; PESSOA, M. L. O impacto dos eventos de estiagem na economia dos municípios do RS. Carta de Conjuntura, v. 12, n. 22, 2013.

ENGLE, D. M.; FUHLENDORF, S. D.; ROPER, A.; LESLIE Jr., D. M. Invertebrate Community Response to a Shifting Mosaic of Habitat. Rangeland Ecology \& Management, v. 61, p. 55-62, 2008. https://doi.org/10.2111/06-149R2.1

GAO, B. NDWI-A Normalized Difference Water Index for Remote Sensing of Vegetation Liquid Water From Space. Remote Sensing of Environment, v. 58, p. 257-266, 1996. https://doi.org/10.1016/S0034-4257(96)00067-3

HAINES-YOUNG, R.; POTSCHIN, M.; KIENAST, F. Indicators of ecosystem services potential at European scales: mapping marginal changes and trade-offs. Ecological Indicators, v. 21, p. 39-53, 2012. https://doi.org/10.1016/j.ecolind.2011.09.004

INSTITUTO DE PESQUISAS HIDRÁULICAS - IPH. Universidade Federal do Rio Grande do Sul. Identificação das alternativas possíveis e prováveis para regularização da vazão do rio Gravataí-RS. Porto Alegre: IPH/CPRM, 2002.

INSTITUTO NACIONAL DE METEOROLOGIA - INMET (Brasil). Dados meteorológicos históricos. $2016 . \quad$ Available in: http://www.inmet.gov.br/portal/index.php?r=estacoes/estacoesConvencionais. Access: Feb. 2019.

JUNK, W. J. Flood pulsing and the linkages between terrestrial, aquatic, and wetland systems. SIL Proceedings, 1922-2010, v. 29, p. 11-38, 2005. https://doi.org/10.1080/03680770.2005.11901972

JUNK, W. J.; BAYLEY, P. B.; SPARKS, R. E. The flood pulse concept in river-floodplain systems. Canadian Journal of Fisheries and Aquatic Sciences, v. 106, p. 110-127, 1989.

JUNK, W. J. et al. Definição e classificação das áreas úmidas (AUs) brasileiras: base científica para uma nova política de proteção e manejo sustentável. Cuiabá: INAU/CPP, 2012.

KLEINDL, W. J.; RAINS, M. C.; MARSHALL, L. A.; HAUER, F. R. Fire and flood expand the floodplain shifting habitat mosaic concept. Freshwater Science, v. 34, n. 4, p. 13661382, 2015. https://doi.org/10.1086/684016

LIM, I. E.; WILSON, S. K.; HOLMES, T. H.; NOBLE, M. M.; FULTON, C. J. Specialization within a shifting habitat mosaic underpins the seasonal abundance of a tropical fish. Ecosphere, v. 7, n. 2, p. 1-13, 2016. https://doi.org/10.1002/ecs2.1212

LIMA, G.; SILVA, M.; CURI, N.; SILVA, M.; OLIVEIRA, A.; AVANZI, J. C.; UMMUS, M. E. Avaliação da cobertura vegetal pelo índice de vegetação por diferença normalizada (IVDN). Revista Ambiente \& Água, v. 8, n. 2, p. 204-214, 2013. http://dx.doi.org/10.4136/ambi-agua.959

LUQUE, S.; SAURA, S.; FORTI, M. J. Landscape connectivity analysis for conservation: insights from combining new methods with ecological and genetic data. Landscape Ecology, v. 27, n. 2, p. 53-157, 2012. https://doi.org/10.1007/s10980-011-9700-5 
MILNE, R.; BENNETT, L. Biodiversity and ecological value of conservation lands in agricultural landscapes of southern Ontario, Canada. Landscape Ecology, v. 22, n. 5, p. 657-670, 2007. https://doi.org/10.1007/s10980-006-9063-5

NEIFF, J. J. Planícies de inundação são Ecótonos? In: HENRY, R. Ecótonos nas interfácies dos sistemas aquáticos. São Carlos: UFSCar, 2003.

PIAZZA, B. P.; ALLEN, Y. C.; MARTIN, R.; BERGAN, J. F.; KING, K.; JACOB, R. Floodplain conservation in the Mississippi River Valley: combining spatial analysis, landowner outreach, and market assessment to enhance land protection for the Atchafalaya River Basin, Louisiana, U.S.A. Restoration Ecology, v. 23, p. 65-74, 2014. https://doi.org/10.1111/rec.12120

RELF, K. Rio Gravataí chega a 5,55 metros e pode aumentar em Cachoeirinha. Correio do Povo, 17 July 2015. Available in: http://www.correiodopovo.com.br/Noticias/561994/Rio-Gravatai-chega-a-5,55-metrosem-Cachoeirinha-. Access: 2017.

RIO GRANDE DO SUL. Plano de Bacia Hidrográfica do Rio Gravataí. Porto Alegre: Comitê Gravatahy, 2011.

ROSSATO, M. S. Os Climas do Rio Grande do Sul: variabilidade, Tendências e Tipologia. 2011. Tese (Doutorado em Geografia) - Universidade Federal do Rio Grande do Sul, Porto Alegre, 2011.

SANCHES, R. A.; ROSSETE, A. N.; REZENDE, A. C. P.; ALVES, H. Q.; VILLAS-BÔAS, A. Subsídios para a proteção de Áreas Úmidas da bacia do rio Xingu (Mato Grosso, Brasil). Revista Árvore, v. 1, p. 489-498, 2012. https://doi.org/10.1590/S010067622012000300011

SCHERER, R. S. Urbanização na planície inundável do rio Gravataí, RS. 2014. Dissertação (Mestrado em Geografia) - Universidade Federal do Rio Grande do Sul, Porto Alegre, 2014.

SCHINDLER, S.; SEBESVARI, Z.; DAMM, C. et al. Multifunctionality of floodplain landscapes: relating management options to ecosystem services. Landscape Ecology, v. 29, p. 229-244, 2014. https://doi.org/10.1007/s10980-014-9989-y

SIMIONI, J. P. D.; GUASSELLI, L. A.; ETCHELAR, C. B. Connectivity among Wetlands of EPA of Banhado Grande, RS. RBRH, v. 22, e15, 2017. http://dx.doi.org/10.1590/23180331.011716096

STANFORD, J. A.; LORANG, M. S.; HAUER, F. R. The shifting habitat mosaic of river ecosystems. SIL Proceedings, 1922-2010, v. 29, p. 123-136, 2005. https://doi.org/10.1080/03680770.2005.11901979

TISCHENDORF, L.; FAHRIG, L. How should we measure landscape connectivity? $\begin{array}{llllllll}\text { Landscape } & \text { Ecology, } & \text { v. } 15, \quad \text { n. } & \text { 7, } & \text { p. 633-641, }\end{array}$ https://doi.org/10.1023/A:1008177324187

TITTENSOR, D. P. Biodiversity: Temperate hotspots. Nature, v. 501, p. 64-78, 2013. https://doi.org/10.1038/501494a

TRACY-SMITH, E.; GALAT, D. L.; JACOBSON, R. B. Effects of flow dynamics on the Aquatic-Terrestrial Transition Zone (ATTZ) of lower Missouri river sandbars with implications for selected biota. River Research and Applications, v. 28, p. 793-813, 2012. https://doi.org/10.1002/rra.1492 
VANDERHOOF, M.; ALEXANDER, L. C.; TODD, M. J. Temporal and spatial patterns of wetland extent influence variability of surface water connectivity in the Prairie Pothole Region, United States. Landscape Ecology, v. 31, p. 805-824, 2016. https://doi.org/10.1007/s10980-015-0290-5

WANG, P. C.; FINLEY, J. C. A landscape of shifting-mosaic steady state in Lassen Volcanic National Park, California. Ecological Research, v. 26, p. 191-199, 2011. https://doi.org/10.1007/s11284-010-0776-1

WIMBERLY, M. C. Species dynamics in disturbed landscapes: when does a shifting habitat mosaic enhance connectivity? Landscape Ecology, v. 21, p. 35-46, 2006. https://doi.org/10.1007/s10980-005-7757-8 